\begin{tabular}{|l|c|c|c|c|c|}
\hline J. Tek. Ling & Vol. 13 & No. 1 & Hal. 37 - 46 & Jakarta, Januari 2012 & ISSN 1441-318X \\
\hline
\end{tabular}

\title{
EVALUASI KARAKTERISASI DAN KESESUAIAN LAHAN UNTUK KOMODITAS UNGGULAN PERKEBUNAN : STUDI KASUS KABUPATEN KAMPAR
}

\author{
Mubekti \\ Peneliti di Pusat TISDA - Kedeputian Bidang TPSA - BPPT \\ e-mail: mubekti@webmail.bppt.go.id
}

\begin{abstract}
Abstrak
Inventarisasi sumberdaya lahan dalam kaitannya dengan penentuan kesesuaian lahan merupakan hal yang harus dilakukan dalam analisis perencanaan wilayah. Studi tentang kemampuan lahan di Kabupaten Kampar, Riau telah dilakukan dengan tujuan untuk mengevaluasi kesesuaian lahan untuk pengembangan perkebunan. Informasi umum lingkungan fisik disajikan untuk mengetahui secara sekilas tentang wilayah studi. Metodologi klasifikasi kesesuaian lahan disampaikan dalam tulisan ini, kemudian hasil analisisnya didiskusikan. Berdasarkan bentuk lahan, wilayah studi dibagi menjadi 8 grup fisiografi, yaitu kubah gambut, aluvial, dataran tufa masam, dataran, karst, perbukitan, pegunungan dan aneka bentuk lahan. Bentuk lahan yang paling luas ditempati oleh fisiografi dataran, sementara yang paling sempit luasannya adalah fisiografi karst. Sebagian besar lahan di wilayah studi masuk kelas sesuai untuk komoditas unggulan perkebunan, terutama untuk tanaman kelapa sawit, karet, kelapa dan kakao. Namun demikian, lahan yang sesuai tersebut didominasi oleh kelas sesuai marjinal. Sementara itu kesesuaian lahan untuk komoditas gambir sebagian besar masuk katagori tidak sesuai. Sebagian lahan yang mempunyai kelas lebih rendah dalam kesesuaian lahan aktual dapat ditingkatkan kelasnya dalam kesesuaian lahan potensial asalkan faktorfoktor pembatas lahan dapat diperbaiki. Faktor-faktor pembatas lahan terdiri dari dua jenis, yaitu (1) faktor pembatas permanen yang tidak dapat diperbaiki, misalnya lereng, tekstur tanah, ketinggian (altitude), dan (2) faktor pembatas yang dapat diperbaiki, misalnya kesuburan lahan, unsur racun $\mathrm{Al}$, kemasaman tanah.
\end{abstract}

kata kunci: Satuan lahan, kesesuaian lahan, GIS, Remote Sensing

\begin{abstract}
Land resource inventories to determine land suitabilities have become standard part of planning analysis. A study of land carriying capacity in kampar District, Riau has been done aiming to evaluate the suitability of land for plantation crops. General information regarding to physical environment of study area are presented in order to know an overview of the study area. The Methodology of land suitability classification corresponding to the selected plantation crops are briefly explained, then, the results of the study are discussed. The study area is divided into 8 group of fisiographic land units, namely, peat dome, alluvial, acid tuff plain, plain, karst, hilly, mountain and miscellaneous landform. The largest one is occupied by plain fisiographic and the smallest one is occupied karst fisiographic. Most of the land is suitable for selected plantation crops, especially for palm oil, rubber, coconut, and cocoa. But, those of suitable land is
\end{abstract}


dominated by marginally suitable category. Whereas for gambier crop shows that most of the land is classified into unsuitable category. A part of the lower class in the actual suitability could be improved to a higher class in the potential suitability depending on limiting factors. There are two types limiting factors to define land suitability, i.e., (1) permanently (un-improvable) limiting factors, such as slope, soil texture, latitude and (2) improvable limiting factors, such as soil fertility, Al toxicity, soil acidity.

key word: land unit, land suitability, GIS, Remote Sensing

\section{PENDAHULUAN}

\subsection{Latar Belakang}

Lahan merupakan sumberdaya fisik wilayah utama yang sangat penting untuk diperhatikan dalam perencanaan tataguna tanah. Lahan merupakan sumberdaya yang terbatas dan tidak terbaharui (non-renewable resource), sedangkan dipihak lain, manusia yang memerlukan lahan jumlahnya bertambah sekitar 1,49 persen/tahun ${ }^{1)}$. Sebagai konsekuensi pertambahan penduduk dan meningkatnya laju pembangunan, sering terjadi konflik kepentingan dan pemanfaatannya mengabaikan kaidah-kaidah pembangunan berkelanjutan.

Evaluasi lahan merupakan suatu proses penilaian potensi suatu lahan untuk penggunaan-penggunaan tertentu ${ }^{2}$. Penggunaan lahan yang tidak sesuai dengan kemampuannya, disamping dapat menimbulkan terjadinya kerusakan juga akan meningkatkan masalah kemiskinan dan masalah sosial lain. Karena itu, evaluasi lahan merupakan salah satu mata rantai yang harus dilakukan agar rencana tataguna lahan dapat tersusun dengan baik. Dalam perencanaan tataguna tanah, perlu diketahui terlebih dahulu potensi dan kesesuaian lahannya untuk berbagai jenis penggunaan tanah, yang dapat diperoleh dengan cara melakukan survai dan pemetaan tanah.

Kabupaten Kampar mempunyai potensi sumberdaya lahan yang besar, dimana menurut data Kampar Dalam Angka tahun 2009 luasannya sebesar 1,1 juta hektar. Di pihak lain, laju pertumbuhan penduduk di wilayah ini juga sangat tinggi dibandingkan dengan rata-rata pertumbuhan penduduk nasional, yaitu mencapai $5 \%$ dalam kurun lima tahun terakhir. Konversi lahan sebagai akibat pertumbuhan penduduk yang pesat tersebut tidak dapat dihindari di wilayah ini. Konversi terbesar adalah lahan hutan menjadi penggunaan lainnya, dimana pada tahun 2005 luasan hutan sebesar 546.730 hektar menjadi 196.505 hektar, atau terjadi pengurangan sekitar lebih dari 350.000 hektar. Sedangkan penggunaan lahan yang meningkat dengan pesat adalah perkebunan, dimana pada tahun 2005 luas perkebunan sebesar 241.499 hektar menjadi 353.505 hektar, atau terjadi peningkatan lebih dari 112.000 hektar. Hal tersebut mengindikasikan perlunya evaluasi daya dukung lahan berdasarkan kesesuaiannya agar dapat dijadikan pedoman dalam perencanaan penggunaan lahan yang bijaksana.

\subsection{Tujuan}

Adapun tujuan dari penelitian ini adalah mengevaluasi sifat-sifat dan kesesuaian lahan lahan untuk komoditas unggulan perkebunan di Kabupaten Kampar. Manfaat yang diharapkan dari hasil studi ini adalah untuk pedoman dalam pengembangan pertanian terutama perkebunan serta dalam perencanaan penatagunaan tanah di wilayah ini.

\section{KONDISI UMUM}

\subsection{Geografi}

Kabupaten Kampar dengan luas lebih kurang 1.128.928 Ha merupakan daerah 
yang terletak antara 01000'40" Lintang Utara sampai 00027'00" Lintang Selatan dan 100028'30" - 101014'30" Bujur Timur. Batas-batas daerah Kabupaten Kampar adalah Kota Pekanbaru dan Kabupaten Siak di sebelah utara, Kabupaten Sengingi di sebelah selatan, Kabupaten Rokan Hulu dan Sumatra Barat di sebelah barat, serta Kabupaten Palalawan di sebelah timur. Secara administratif Kabupaten Kampar merupakan salah satu Kabupaten di Provinsi Riau yang terbagi menjadi 21 Kecamatan.

Kabupaten Kampar masuk dalam wilayah yang beriklim tropis, dan tidak menunjukkan perbedaan iklim yang mencolok antar lokasi.. Curah hujan rata-rata tahunan pada umumnya cukup tinggi, yaitu antara 2000-3000 mm, dengan jumlah hari hujan rata-rata tahunan berkisar antara 112-182 hari. Berdasarkan data dari stasiun cuaca di Pekanbaru temperatur minimum terjadi pada bulan Juni yaitu sebesar $21,4^{\circ} \mathrm{C}$. Temperatur maksimum terjadi pada September dengan temperatur $35,6^{\circ} \mathrm{C}$.

Di daerah Kabupaten Kampar terdapat dua buah sungai besar, yaitu dan beberapa sungai kecil yaitu Sungai Kampar dengan panjang $\pm 413,5 \mathrm{~km}$ dan Sungai Siak dengan panjang $\pm 90 \mathrm{~km}$. Sungai-sungai besar yang terdapat di Kabupaten Kampar ini sebagian masih berfungsi baik sebagai prasarana perhubungan, sumber air bersih budi daya ikan maupun sebagai sumber energi listrik (PLTA Koto Panjang).

\subsection{Penggunaan Lahan}

Hampir setengah dari luas wilayah Kabupaten Kampar merupakan kawasan budidaya dengan tingkat kesuburan yang cukup baik ${ }^{3)}$. Namun demikian dari pemanfaatan lahan yang ada masih belum maksimal penggunaannya terhadap kegiatan produktif, misalnya masih ada padang rumput dan tanah yang terlantar lainnya yang cukup luas, yaitu mencapai lebih dari 55 ribu hektar. Penggunaan lahan yang paling dominan adalah perkebunan disusul kemudian untuk kehutanan. Tegalan untuk kebun campuran dan ladang mempnyai luasan yang relative besar kemudian disusul dengan lahan untuk pekarangan.

Angka luasan penggunaan lahan dari tahun 2005 sampai dengan tahun 2009, menunjukkan bahwa telah terjadi konversi lahan yang signifikan selama kurun 5 tersebut. Konversi terbesar adalah lahan hutan menjadi penggunaan lainnya, dimana pada tahun 2005 luasan hutan sebesar 546.730 hektar menjadi 196.505 hektar pada tahun, atau terjadi pengurangan sekitar lebih dari 350.000 hektar. Sedangkan penggunaan lahan yang meningkat dengan pesat adalah perkebunan dan tegalan untuk kebun campuran. Sedangkan lahan persawahan menunjukkan kecenderungan menurun selama kurun 5 tahun, yaitu terjadi penurunan lebih dari 2000 hektar.

\subsection{Kondisi Perkebunan}

Bentuk usaha perkebunan di Kabupaten Kampar ada tiga macam, yaitu (1) usaha perkebunan rakyat, (2) usaha perkebunan besar negara, dan (3) usaha perkebunan swasta. Berdasar data4) luas areal perkebunan hingga tahun 2010 mencapai 468.917 ha atau lebih $40 \%$ dari luas wilayah Kabupaten Kampar. Berdasarkan bentuk usahanya, areal perkebunan yang paling luas adalah perkebunan rakyat, kemudian perkebunan besar swasta, dan baru perkebunan besar negara.

Data 5 tahun terakhir (2006-2010) menunjukkan, bahwa laju pertumbuhan luas areal perkebunan yang paling pesat adalah perkebunan besar swasta yang mencapai rata-rata $11,94 \%$ per tahun, disusul oleh perkebunan rakyat yang mencapai 3,23\% per tahun, sedangkan perkebunan besar negara tidak mengalami perkembangan dari tahun 2006 sampai dengan 2010. Secara keseluruhan laju pertumbuhan luas areal perkebunan di Kabupaten Kampar mengalami peningkatan rata-rata sebesar $5,62 \%$ per tahun. 
Total produksi perkebunan sebesar 5.434.376 ton. Berbeda dengan luas areal yang didominasi oleh perkebunan rakyat, maka produksi tanaman perkebunan lebih didominasi oleh perkebunan besar swasta. Produksi perkebunan swasta pada tahun 2010 mencapai 2.998 .456 ton $(55,18$ $\%$ ), disusul oleh perkebunan rakyat yang mencapai 1.906.035 ton (35,07 \%), sisanya berasal dari perkebunan besar negara yang mencapai 529.885 ton $(9,75 \%)$.

Komoditas perkebunan yang dominan diusahakan tahun 2010 adalah kelapa sawit dan karet. Luas areal perkebunan kelapa sawit pada tahun 2010 mencapai luas 359.806 ha $(76,73 \%)$, disusul komoditas karet seluas 101.174 ha $(21,58 \%)$, dan sisanya terdiri atas komoditas gambir, kelapa, dan komoditas lainnya.

Sejalan dengan dominasi luas areal komoditas kelapa sawit dan karet, maka produksi perkebunan juga didominasi oleh produksi kelapa sawit dan karet. Produksi kelapa sawit pada tahun 2010 mencapai 5.353 .628 ton $(98,51 \%)$, kemudian karet sebesar 75.108 ton $(1,38 \%)$. Sisanya merupakan produksi dari gambir, kelapa, dan lainnya masing-masing 4.540 ton, 1.044 ton, dan 55 ton.

\section{METODOLOGI}

Tahapan yang dilakukan dalam evaluasi lahan untuk kesesuian meliputi evaluasi kualitas lahan melalui pemetaan satuan Iahan, evaluasi persyaratan tumbuh tanaman, dan evaluasi kesesuaian lahan untuk masing-masing komoditas perkebunan. Prinsip dari analisis kesesuaian lahan adalah mencocokkan persyaratan tumbuh tanaman dengan kualias lahan²). Evaluasi satuan lahan dan kesesuaiannya berdasar kaidah-kaidah yang berlaku dan operasionalisasinya menggunakan soft-ware Arc-GIS. Sedangkan komoditas unggulan perkebunan yang dianalisis meliputi kelapa sawit, karet, gambir, kelapa, dan kakao. Penentuan komoditas tersebut merupakan hasil wawancara dengan pihak-pihak terkait berdasar nilai ekonomis, prospek ekspor, dan penyerapan tenaga kerja.

\subsection{Evaluasi Kualitas Lahan}

Tujuan evaluasi kualitas lahan adalah mengevaluasi sifat-sifat fisik lahan yang diwujudkan dalam peta satuan lahan. Peta ini dibangun dari analisis dan interpretasi data peta kontur, Citra satelit Landsat TM, peta geologi skala 1:00.000, data sekunder lainnya, serta survai lapangan.

Klasifikasi peta satuan lahan didasarkan pada parameter-parameter fisik lahan yang menjadi faktor pembatas apabila akan dimanfaatkan untuk pengembangan komoditas perkebunan5,6). Parameterparameter tersebut meliputi: (1) Kemiringan lereng; (2) Tingkat kerentanan erosi; (3) Tingkat kerentanan banjir; (4) Kedalaman tanah; (5) Tekstur tanah; (6) Drainase tanah; (7) Keasaman tanah; (8) Salinitas; (9) Iklim.

\subsection{Evaluasi Kesesuaian lahan}

Klasifikasi kesesuaian lahan yang dilakukan untuk penelitian ini menggunakan kriteria hasil modifikasi yang dikemukakan dalam Atlas Format Procedure ${ }^{7)}$ dan Petunjuk Teknis Evaluasi Lahan8). Evaluasi kesesuaian lahan dilakukan dengan mengevaluasi sifat-sifat fisik yang terdapat peta satuan lahan dan dicocokkan dengan persyaratan tumbuh komoditas unggulan yang dinilai, sehingga dapat ditentukan kelas kesesuaian dari setiap unit lahan.

Pada studi ini evaluasi kesesuaian lahan dilakukan sampai tingkat sub-kelas. Kelas adalah keadaan tingkat kesesuaian dalam tingkat ordo. Selanjutnya kelas dibedakan berdasarkan tingkat kecocokan, yaitu lahan yang tergolong ordo sesuai (S) dibedakan ke dalam tiga kelas, yaitu : lahan sangat sesuai (S1), cukup sesuai (S2), dan sesuai marginal (S3). Sedangkan untuk Ordo tidak sesuai $(\mathrm{N})$ biasanya tidak diperinci lebih lanjut. 
Subkelas adalah keadaan tingkatan dalam kelas kesesuaian lahan. Kelas kesesuaian lahan dibedakan menjadi subkelas berdasarkan kualitas dan karakteristik lahan (sifat-sifat tanah dan lingkungan fisik lainnya) yang menjadi faktor pembatas terberat, misal Subkelas S3rx sesuai marginal dengan pembatas kondisi perakaran ( $r=$ rooting condition) dan bahaya bahan racun kejenuhan Aluminium (x). Jadi huruf kecil sebagai indek di belakang kelas merupakan faktor pembatas utama yang bisa lebih dari satu jenis. Faktor-faktor pembatas tersebut meliputi ketinggian tempat (h), ketersediaan air (w), media perakaran (r), retensi hara (f), toksisitas (x), ketersediaan hara $(n)$, topografi (s), dan tingkat bahaya banjir (b).

\section{HASIL DAN PEMBAHASAN}

\subsection{Evaluasi Satuan Lahan}

Satuan lahan adalah kelompok lahan yang mempunyai sifat-sifat yang sama atau hampir sama yang penyebarannya digambarkan dalam peta satuan lahan, dimana peta ini sebagai dasar dalam evaluasi kesesuaian lahan. Peta ini dibangun dari analisis dari hasil penelitian terdahulu dan didukung dengan interpretasi data satelit, peta topografi dan pengamatan lapangan. Peta-peta satuan lahan hasil penelitian terdahulu di Kabupaten Kampar adalah peta satuan lahan lembar Solok dan lembar Pekanbaru yang diproduksi oleh Pusat Penelitian Tanah dan Agroklimat ${ }^{9}$.

Secara garis besar lahan di Kabupaten Kampar dapat dikelompokkan kedalam 8 grup berdasarkan fisiografinya, yaitu Grup Kubah Gambut (D), Grup Aluvial (A), Grup Dataran Tuf Masam (I), Grup Dataran (P), Grup Karst (K), Grup Perbukitan (H), Grup Pegunungan (M) dan Grup Aneka Bentuk Wilayah (X). Kemudian dari 8 grup fisiografi tersebut terbagi menjadi 77 satuan lahan. Pada tingkat ordo menurut sistem Taksonomi Tanah ${ }^{10)}$,jenis tanah di wilayah Kampar didominasi oleh Inceptisol, Histosol, Oxisol, Ultisol dan Entisol. Inceptisol mempunyai penyebaran dan luasan yang paling dominan di wilayah ini. Penyebaran Inceptisol, Oxisol, Ultisol dan Entisol hampir di semua fisiografi kecuali fisiografi kubah gambut, sedangkan Histosol terutama di fisiografi kubah gambut dan sebagian kecil di fisiografi alluvial. Dalam sistem lama ${ }^{11)}$ Soepraptohardjo dalam ${ }^{11)}$, padanan Inceptisol adalah tanah Aluvial atau Latosol atau Podsolik coklat. Padanan Histosol adalah Organosol, Oxisol dengan Latosol, Ultisol dengan Podsolik merah-kuning, dan Entisol dengan Regosol. Pengelompokan dalam satuan lahan didasarkan pada karakteristik fisik dari lahan yang berkaitan erat sifat-sifatnya, misalnya bahan induk, topografi, iklim, media perakaran dan lain-lain. Simbul pada peta satuan lahan mengindikasikan karakteristik spesifik dari masing-masing satuan lahan. Huruf besar menunjukkan grup fisiografi, kemudian huruf kecil dibelakang huruf besar menunjukkan jenis batuan induk. Pembagian lebih lanjut berdasarkan atas bentuk lahan (relief), lereng, dan tingkat torehan atau berdasarkan lingkungan pengendapan/ hidrologinya serta adanya pengeruh manusia yang ditunjukkan oleh simbul angka. Gambar 1 , adalah peta satuan lahan hasil evalusi karakterisasi lahan di Kabupaten Kampar.

Pada fisiografi kubah gambut terdapat 3 satuan lahan yang menempati areal seluas $117.737,4$ hektar atau 10,3\% dari total luas wilayah Kabupaten Kampar. Fisiografi alluvial terbagi menjadi 9 satuan lahan yang menempati areal seluas 107.854,8 hektar atau 9,4\% dari total luas wilayah Kabupaten Kampar. Kemudian di fisiografi dataran tufa masam terdapat 6 satuan lahan menempati areal seluas 32.492,9 hektar atau 2,8\% dari total wilayah. Grup fisiografi yang paling banyak satuan lahannya adalah fisiografi dataran, dimana terdapat 34 satuan lahan dan menempati luasan yang paling besar, yaitu 597.338,9 hektar atau $52 \%$ dari total wilayah. Grup fisiografi perbukitan terbagi menjadi 15 satuan lahan menempati luasan 
$135.038,3$ hektar atau 11,8 \% dari total wilayah. Fisiografi Karst hanya terdapat satu satuan lahan yang menempati luasan $1.225,2$ hektar atau $0,1 \%$ dari total wilayah. Grup fisiografi Pegunungan terbagi menjadi 9 satuan lahan menempati luasan 151.760,0 hektar atau 13,2 \% dari total wilayah. Sedangkan Grup aneka bentuk lahan menempati luasan 2.783,4 hektar atau 0,2 $\%$ dari total wilayah, namun tidak dianalisis. setiap satuan lahan dinilai berdasarkan kecocokannya terhadap persyaratan tumbuh dari masing-masing komoditas. Adapun komoditas unggulan perkebunan yang dianalisis adalah kelapa sawit (Elaeis guineensis), karet (Hevea brasiliensis), gambir (Uncaria gambir Roxb.), kelapa (Cocos nucifera), dan kakao (Theobroma cacao).

Seperti yang disebutkan di dalam

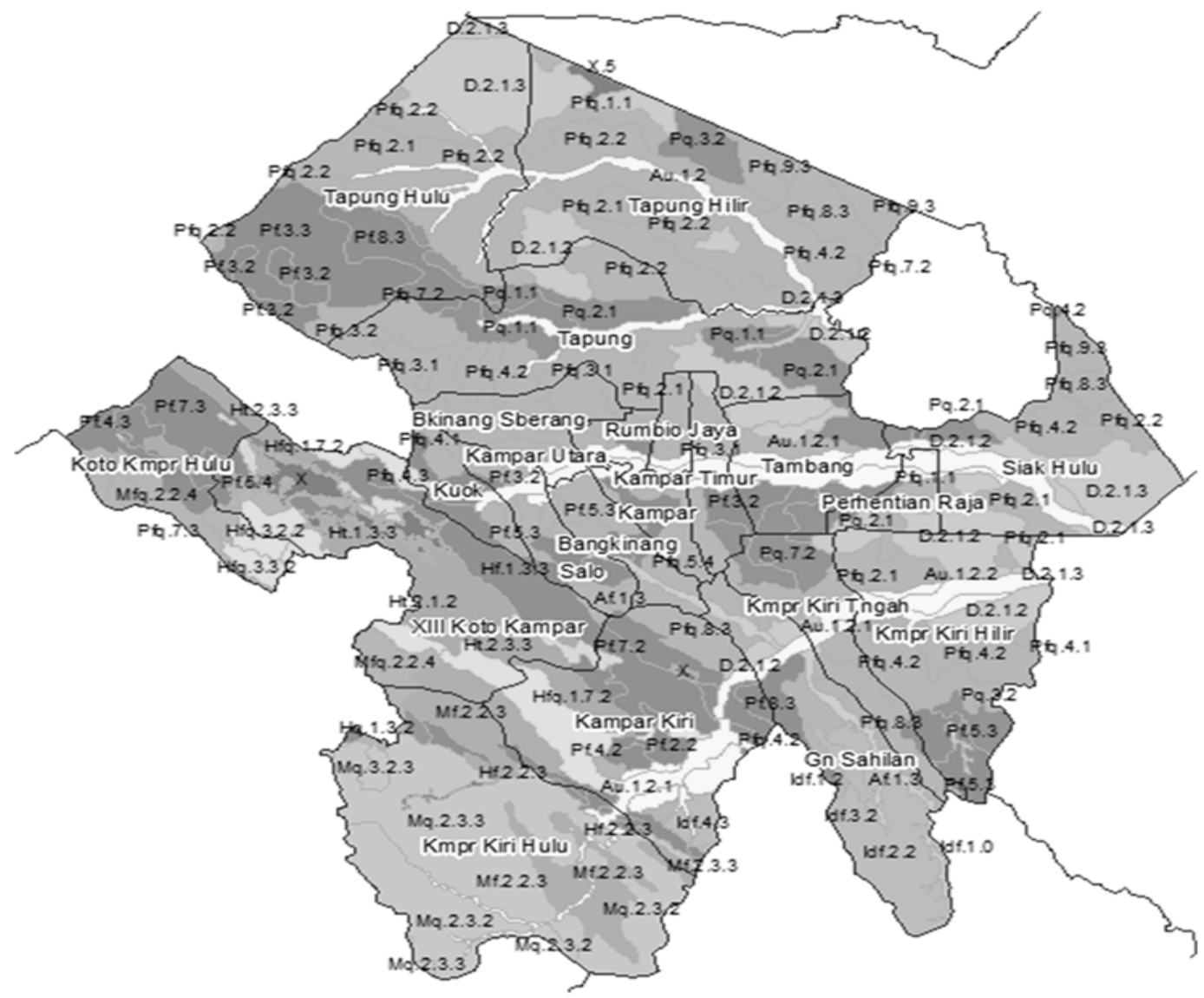

Gambar 1. Peta Satuan Lahan Kab. Kampar

\subsection{Evaluasi Kesesuaian Lahan}

Evaluasi kesesuaian lahan dilakukan berdasarkan pencocokan antara karakteristik lahan dan persyaratan tumbuh dari masing-masing jenis komoditas/ tanaman. Berdasarkan karakter-karakternya, metodologi, bahwa evaluasi kesesuaian lahan dilakukan sampai tingkat subkelas baik kesesuaian aktual maupun potensial. Kesesuaian lahan aktual atau kesesuaian lahan pada saat ini (current suitability) belum mempertimbangkan usaha perbaikan untuk mengatasi kedala atau faktor-faktor 
pembatas yang ada di setiap satuan lahan. Sedangkan kesesuaian lahan potensial adalah kesesuaian lahan yang akan dicapai setelah dilakukan usaha-usaha perbaikan terhadap sifat-sifat lahan.

Hasil evaluasi menunjukkan, bahwa kelas kesesuaian aktual tertinggi hanya sampai pada katagori kelas cukup sesuai (S2). Menurut $\left.{ }^{2}\right)$ perbaikan kelas dari aktual ke potesial berubah maksimal manjadi satu atau dua tingkat lebih baik, namun dalam penelitian ini perbaikan hanya satu tingkat lebih baik. Peta kesesuaian aktual tidak disajikan dalam paper namun demikian luasan hasil ekstraksi peta dicantumkan dalam Tabel 1. Gambar 2 adalah salah satu ilustrasi peta hasil evaluasi kesesuaian
Iahan potensial untuk komoditas kelapa sawit, sedangkan ilustrasi peta hasil evaluasi kesesuaian lahan potensial untuk komoditas karet, gambit, kelapa, dan kakao disajikan dalam Lampiran Gambar. Dalam Gambar 2, menunjukkan penyebaran dari masingmasing kelas kesesuaian lahan.

Pada tanah-tanah gambut (Histosol), faktor pembatas media perakaran terutama disebabkan oleh ketebalan gambut dan tingkat kematangannya, sedangkan pada tanah alluvial adalah drainase yang buruk. Faktor pembatas retensi hara terutama disebabkan oleh tingkat kemasaman yang tinggi. Untuk tanaman-tanaman perkebunan yang agak toleran terhadap faktor-faktor pembatas tersebut, kelas kesesuaian

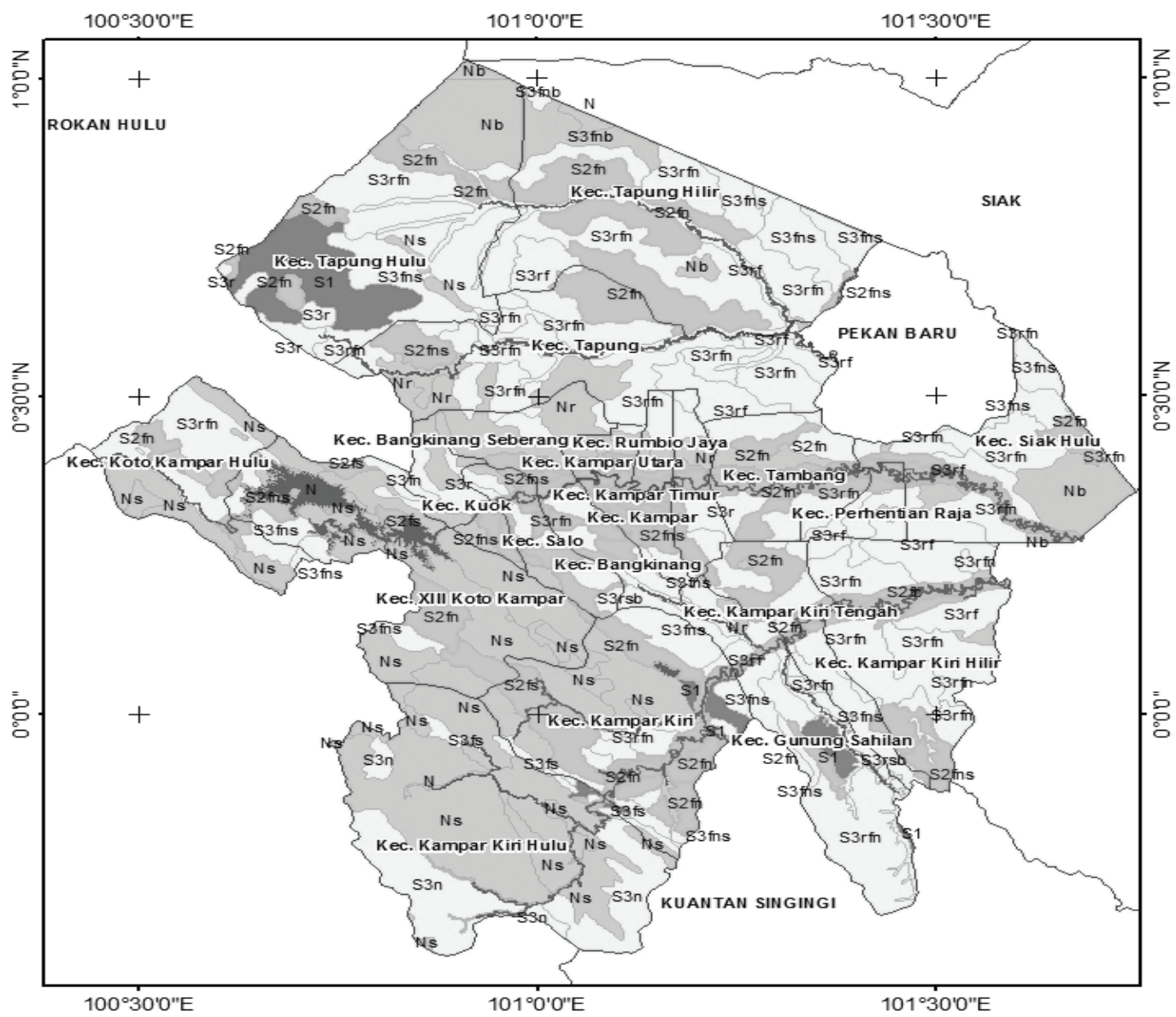

Gambar 2. Hasil peta kesesuaian lahan potensial kelapa sawit 
lahannya masih bisa masuk dalam katagori sesuai. Tanaman gambir yang membutuhkan ketinggian di atas $150 \mathrm{~m}$ dari permukaan laut, tidak cocok pada tanah-tanah alluvial dan tanah gambut ini.

Tanah-tanah pada fisiografi dataran tufa masam dan fisiografi dataran, faktor pembatas utama yang dijumpai adalah media perakaran, retensi hara, dan ketersediaan unsur hara. Faktor pembatas media perakaran terutama disebabkan oleh drainase yang buruk, sedangkan retensi hara terutama disebabkan oleh kemasaman yang tinggi serta kapasitas tukar kation yang rendah. Ketersediaan fosfat dan kalium yang sangat rendah menjadi kendala pada wilayah ini. Namun demikian tanah-tanah yang ada di wilayah ini pada umumnya cukup sesuai untuk tanaman perkebunan. Fisiografi dataran tufa masam dan dataran terletak pada ketinggian di bawah $150 \mathrm{~m}$ sehingga masih tidak sesuai untuk tanaman gambir. Untuk tanah-tanah yang mempunyai faktor pembatas ringan seperti retensi hara dan ketersediaan unsur hara dapat ditingkatkan kelasnya pada kesesuaian lahan potensial. Dalam Tabel 1 terlihat bahwa di wilayah ini terutama di fisiografi tufa masam tingkat kesesuaiannya dapat ditingkatkan menjadi cukup sesuai (S2) maupun sangat sesuai (S1), kecuali untuk tanaman gambir yang mempunyai faktor pembatas permanen yaitu ketinggian.

Usaha perkebunan pada kawasan fisiografi perbukitan, pegunungan dan Karst masih dijumpai faktor pematas utama terrain terutama yang disebabkan oleh lereng yang terjal sampai sangat terjal, walaupun untuk lokasi-lokasi tertentu masih bisa diusahakan untuk perkebunan. Faktor pembatas lereng ini bersifat permanen dalam arti sangat sulit untuk diperbaiki apabila akan dibuka untuk usaha pertanian. Pada wilayah ini dijumpai tanah-tanah yang sesuai untuk dibudidayakan tanaman gambir, yaitu pada tanah-tanah yang tidak terlalu terjal dan ketinggiannya lebih dari 150 m dari permukaan laut.

Total luas wilayah Kabupaten Kampar adalah 1.146.228,8 hektar dan Iuasan berdasarkan hasil klasifikasi kesesuaian lahan baik secara aktual dan potensial untuk masing-masing komoditas unggulan perkebunan seperti yang terlihat dalam Tabel 1. Tabel ini merupakan kesesuaian tingkat kelas yang merupakan penggambungan dari sub-kelas seperti yang terlihat dalam peta kesesuaian lahan.

Hasil luasan seperti yang terlihat dalam Tabel 1, menunjukkan bahwa sebagian besar lahan di Kabupaten Kampar masuk dalam katagori kelas sesuai marjinal (S3) baik aktual maupun potensial, kecuali untuk tanaman gambir yang sebagian besar masuk masuk kelas tidak sesuai (N). Perubahan/ perbaikan yang cukup signifikan antara hasil evaluasi kesesuaian aktual dan potensial, terjadi pada kelas S2 (cukup sesuai) berubah menjadi kelas S1 (sangat sesuai) untuk setiap jenis komoditas. Hal tersebut dikarenakan faktor pembatas yang menjadi hambatan untuk tanaman perkebunan pada kelas S1 untuk kesesuaian aktual merupakan pembatas ringan dan dapat diperbaiki,

Tabel 1. Luasan kesesuaian lahan aktual dan potensial untuk tanaman perkebunan $(\mathrm{Ha})$

\begin{tabular}{|l|r|r|r|r|r|r|r|}
\hline \multirow{2}{*}{ Komoditas } & \multicolumn{3}{|c|}{ Kesesuaian Lahan Aktual } & \multicolumn{3}{c|}{ Kesesuaian Lahan Potensial } \\
\cline { 2 - 8 } & \multicolumn{1}{c|}{ S2 } & \multicolumn{1}{c|}{ S3 } & \multicolumn{1}{c|}{$\mathrm{N}$} & \multicolumn{1}{c|}{ S1 } & \multicolumn{1}{c|}{ S2 } & \multicolumn{1}{c|}{ S3 } & \multicolumn{1}{c|}{$\mathrm{N}$} \\
\hline Kelapa Sawit & $67.656,0$ & $765.588,5$ & $312.984,3$ & $35.133,7$ & $246.891,9$ & $551.224,8$ & $312.978,6$ \\
\hline Karet & $131.929,6$ & $614.970,9$ & $399.328,4$ & $99.351,7$ & $181.833,8$ & $528.216,9$ & $336.826,5$ \\
\hline Gambir & $49.530,9$ & $64.204,2$ & $1.032 .493,8$ & $42.109,6$ & $7.421,3$ & $64.204,2$ & $1.032 .493,8$ \\
\hline Kelapa & $15.112,0$ & $755.636,4$ & $375.480,5$ & $11.237,0$ & $242.169,5$ & $579.843,9$ & $312.978,6$ \\
\hline Kakao & $8.442,1$ & $731.290,8$ & $406.496,1$ & $8.442,10$ & $193.926,20$ & $537.364,6$ & $406.496,1$ \\
\hline
\end{tabular}


seperti $\mathrm{pH}$, tingkat ketersediaan hara, dan kejenuhan Al. Sehingga secara potensial sebagian besar lahan dapat ditingkatkan kelas kesesuaiannya menjadi S1. Demikian juga dengan kelas sesuai marjinal (S3) dapat ditingkatkan menjadi lahan cukup sesuai (S2) pada kesesuaian potensial, walaupun luasannya tidak terlalu besar. Kelas tidak sesuai hanya sedikit sekali luasannya yang bisa ditingkatkan menjadi kelas sesuai marjinal pada kesesuaian potensial. Hal tersebut dikarenakan faktor pembatas lahan yang berat dan pada umumnya tidak bisa diperbaiki, seperti lereng, curah hujan, kedalaman tanah dan lain-lain.

Komoditas kelapa sawit dan karet merupakan 2 komoditas yang berpotensi untuk dikembangkan berdasarkan luas lahan yang relatif besar masuk dalam katagori sangat sesuai (S1) dan cukup sesuai (S2). Gambir yang merupakan tanaman spesifik lokasi (endemik), mempunyai kesesuaian potensial katagori sangat sesuai (S1) seluas 42.109,6 hektar sehingga berpotensi untuk dikembangkan. Demikian juga kelapa dan coklat mempunyai potensi untuk dikembangkan di wilayah ini berdasarkan kesesuaian lahannya.

\section{KESIMPULAN DAN SARAN}

1. Secara umum di wilayah studi terdapat 8 grup fisiografi, yaitu: grup Kubah Gambut, Aluvial, Dataran Tuf Masam, Dataran, Karst, Perbukitan, Pegunungan dan grup Aneka Bentuk. Fisiografi yang paling luas adalah fisiografi dataran yang mencapai luasan 597.338,9 hektar atau 52,1\%. Sedangkan grup fisiografi yang paling kecil luasannya adalah fisiografi karst, yaitu $1.225,2$ hektar atau $0,1 \%$ dari total wilayah. Dari 8 grup fisiografi terbagi menjadi 77 satuan lahan.

2. Lahan di daerah studi tingkat kesesuaian aktualnya yang paling tinggi adalah cukup sesuai (S2), namun demikian kesesuaian potensialnya masih dapat ditingkatkan.

3. Faktor pembatas utama dalam penentuan kesesuaian lahan faktor pembatas permanen dan faktor pembatas yang dapat diperbaiki. Faktor pematas permanen di wilayah ini terdiri dari lereng, tekstur tanah, curah hujan, dan ketinggian tempat (altitude), sedangkan faktor pembatas yang dapat diperbaiki berasal dari $\mathrm{pH}$ tanah, toksisitas Al, ketersediaan fosfat dan kalium.

4. Semua komoditas unggulan perkebunan di Kabupaten Kampar, mempunyai prospek yang baik untuk dikembangkan, tidak hanya berdasarkan prospek ekonomi saja tetapi juga prospek berdasarkan kesesuaian lahannya.

\section{DAFTAR PUSTAKA}

1. BPS (Badan Pusat Statistik), 2010. Hasil Sensus Penduduk 2010. http:// sp2010.bps.go.id/files/ebook.

2. Hardjowigeno, S. dan Widiatmaka, 2001. Kesesuaian Lahan dan Perencanaan Tataguna Tanah. Jurusan Tanahn- Fakultas Pertanian, IPB, Bogor.

3. Bappeda (Badan Perencanaan Pembangunan Daerah), 2009. Kampar Dalam Angka, Tahun 2009.

4. Dinas Perkebunan - Pemda Kampar, 2011. Buku Data Perkebunan Kabupaten Kampar, Tahun 2010.

5. FAO. 1976. A Framework for Land Evaluation. Soil Resources Management and Conservation Service Land and Water Development Division. FAO Soil Bulletin No. 32. FAO-UNO, Rome.

6. Marsoedi Ds., Widagdo, Junus Dai, Nata Suharta, Darul SWP, Sarwono dan J Hof. 1997. Pedoman Klasifikasi Landform. Second Land Resource Evaluation And Planning Project (LREP-II) Part C. Laporan Teknis No. 5, Versi 3.0, Maret 1997.

7. FAO/CSR Staffs. 1983. Reconnaissance 
Land resource Sirvey 1: 250.000 Scale. Atlas Format Procedures. AGOF/ INS/78/006. Manual 4. Version 1. Centre for Soil Research, Bogor. Indonesia.

8. Djaenudin, D., Marwan H., Subagyo H., dan A. Hidayat. 2003. Petunjuk Teknis untuk Komoditas Pertanian. Edisi Pertama tahun 2003, ISBN 9799474-25-6. Balai Penelitian Tanah, Pusat Penelitian dan Pengembangan Tanah dan Agroklimat, Badan Litbang Pertanian.

9. Sudihardjo, A.M., H. Sosiawan, H.J.
Deri, Junus Dai, dan A. Hidayat, 1990. Buku Keterangan Peta Satuan Lahan dan Tanah lembar Pekanbaru (0816), Sumatera. Pusat Penelitian Tanah dan Agroklimat, Bogor.

10. Soil Survey Staff. 2003. Keys to Soil Taxonomy, 9 ed. United Stated Department of Agriculture, NRCS. Washington DC

11. Djaenudin, D., 2008. Perkembangan penelitian sumberdaya lahan dan ketersediaannya untuk mengatasi kebutuhan lahan pertanian di Indonesia. Jurnal Litbang Pertanian, 2008.

Lampiran Gambar. Ilustrasi peta hasil kajian kesesuaian lahan untuk komoditas karet, gambir, kelapa dan kakao, Kabupaten Kampar
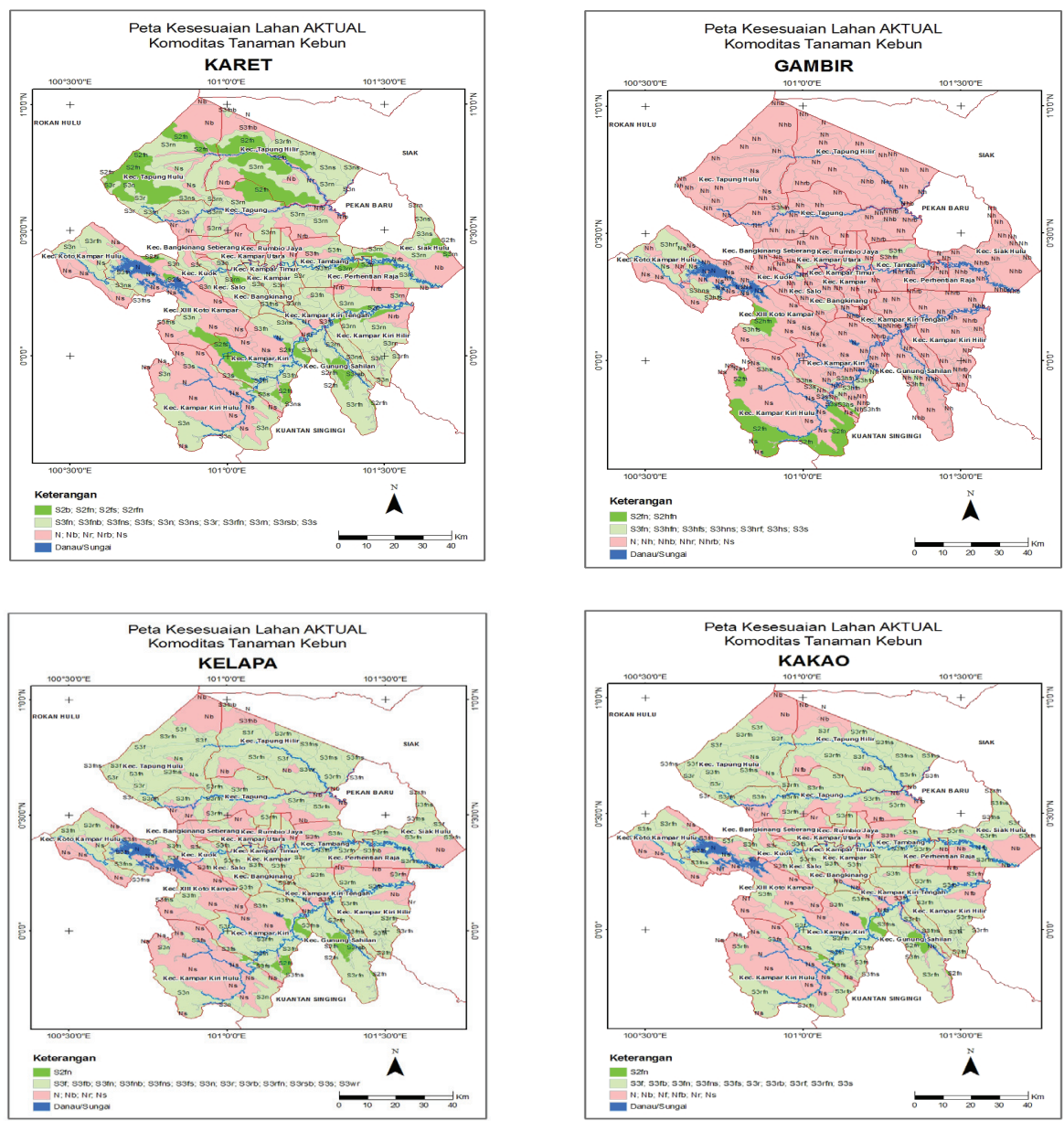